\title{
Ichthyofaunal Diversity of the River Nun Estuary, Niger Delta, Nigeria
}

\author{
Gijo, A. H. ${ }^{1}$, Alagoa, K. J ${ }^{2}$ \\ ${ }^{1,2}$ Department of Biological Sciences, Faculty of Science, Niger Delta University, Amassoma, Bayelsa State, \\ Nigeria. \\ Corresponding Author: Alagoa, K. J
}

DOI: https://doi.org/10.52403/ijrr.20220237

\begin{abstract}
A study of the Ichthyofaunal diversity of the River Nun Estuary, Nigeria was conducted for one calendar year. This was done in order to update the inventory of the fish species and to specify distribution patterns in the River Nun ichthyofauna in order to establish some basis for pollution prevention and the conservation of these fish communities and their habitat. Fishes were collected monthly from six sampling sites of the River Nun Estuary with the help of local skilled fishers. Cast nets, scoop nets, gill nets, beach seine nets, pole seine nets, and hooks and lines were used for capturing fish. Different fish species were collected from fishers at the different fish landings. photographs were immediately taken with the help of a digital camera. Fishes brought to laboratory were preserved in $10 \%$ formalin solution. All fish species were identified to genus and species level using taxonomic keys and standard literature. 60 species of fish that belong to 48 different genera and 27 families were recorded during the study. The families Cichlidae and Gobiidae had the highest number of species (7 species each) followed by the families Claroteidae, Carangidae, Mugilidae, and Characidae (which had 4 species each), Polynemidae (with 3 species), and Clupeidae Tetraodontidae, Carangidae, Sclaenidae (with 2 species each). The families Hepsedae, Dasyatidae, Soleidae, Elopidae, Monodactylidae, Lobotidae, Periophthalmidae, Ophichthidae, Soleidae, Cynoglossidae, Tetraodontidae, Serranidae, Clupeidae, Carangidae, and Haemulidae had just one species. Ethmalosa fimbriata (Bonga shad) of the of the Order Clupeiformes and family
\end{abstract}

Clupeidae was the most abundant species of the River Nun estuary, followed by Pseudotolithus (Foniticulus) elongates (Croaker) of the family Sclaenidae, Periophthalmus barbarous/ papilio (Atlantic mudskipper) of the family Periophthalmidae, Mugil curema (White mullet), Mugil bananensis (Banana mullet), and Liza grandisquamis (Sickle fin mullet) of the family Mugilidae. It can be concluded that the ichthyofaunal composition of the River-Nun compares favorably with other Rivers of similar relevance. There is no cause for concern by all stakeholders about its ecological health and its fishery.

Key Words: Ichthyofauna, Diversity, Estuary, River-Nun, Niger Dela

\subsection{INTRODUCTION}

Fishes are cold-blooded vertebrates that breathe by means of gills, live in water and move with the help of fins. There are about 36,000 species, which represent the $40 \%$ of the total vertebrates present on $\operatorname{earth}^{[1]}$. Fishes are an important natural source of protein and they also provide certain other useful products such as useful fats and oils.

Fishes differ greatly in size, shape, habits and habitats. The smallest fish goby (Mistichthys lozerensis)for instance measures about $1.2 \mathrm{~cm}$ while the largest fish, the whale shark, (Rhinodon) grows up to 20 meters. Therefore, a knowledge of fish biology particularly on morphometry, length-weight relationship, condition factor, reproduction, food and feeding habits of 
utmost important not only to fill up the lacuna of our present-day academic knowledge but also in the utility of the knowledge in increasing the technological efficiencies of the fishery entrepreneurs for evolving judicious pisciculture management [2].

For developing any fishery, it is necessary to understand its population dynamics. Population dynamics is mostly affected by existing ecological factors, chiefly determine by anthropogenic inputs into receiving waters rather than the rates of recruitment and migration into it.

As estuaries, stream and rivers in the Niger Delta region of Nigeria are perennially exposed to anthropogenic activities particularly oil pollution which threatens the survival of various aquatic organisms, particularly fishes, and the source of livelihood of several fish folks, there is an acute societal need to provide a checklist of the ichthyofauna of the Nun River estuary and update the inventory of the fish species and to specify distribution patterns in the River Nun ichthyofauna in order to establish some basis for pollution prevention and the conservation of these fish communities and their habitat.

\subsection{MATERIALS AND METHODS 2.1 Study Area}

The study area is the Nun River Estuary in Akassa kingdom in Brass Local Government Area in Bayelsa State situated in the Niger Delta Region of Nigeria (Figure 1.). Akassa kingdom occupies an area of $120 \mathrm{~km}^{2}$ and is situated on both sides of the Nun River estuary. The population of the inhabitants of the River Nun estuary is about 280,000 inhabiting 21 major towns and several fishing settlements that make up the Akassa kingdom. The Akassa people speak the Izon (Ijaw) language, which is their mother tongue. The Estuary is located along latitude $4^{0} 20^{\prime \prime}$ and $4^{0} 17^{\prime} \mathrm{N}$ and longitude $6^{0} 49^{\prime}$ and $4^{0} 55^{\prime} \mathrm{E}{ }^{[3]}$. The wet season spans from April to November, while the short dry season spans from December to March.

The estuary is interconnected with several creaks, inlets, and canals which serve as navigational routes and drainages in the area. It is also connected to other estuaries through these channels. The RiverNun estuary is bordered to the east by the Brass River estuary and to the west by the Sangana River estuary. It opens up into the Atlantic Ocean at its southern part.

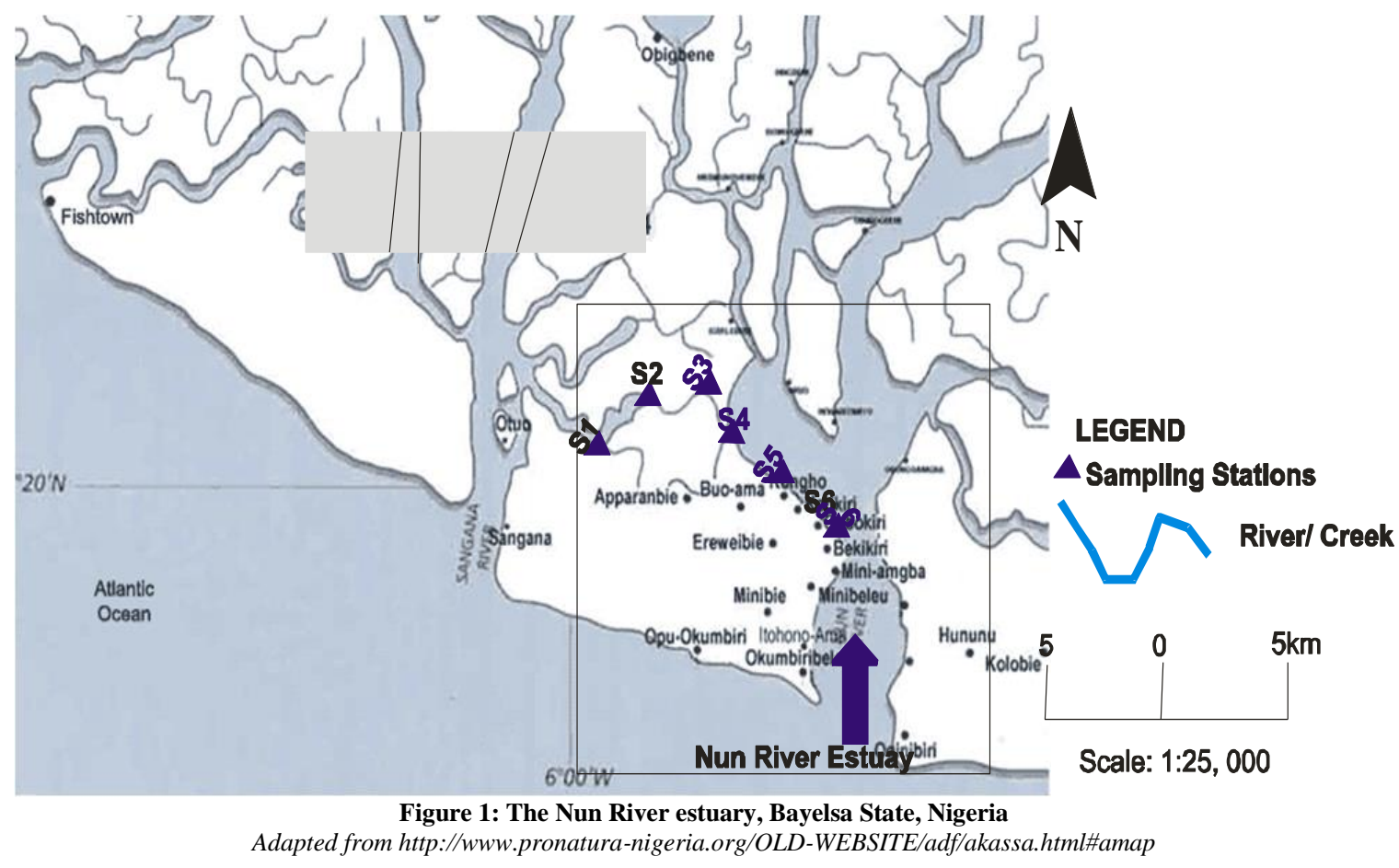




\subsection{Sampling Locations}

Table 1: Coordinates and locations of sampling stations

\begin{tabular}{|c|c|c|c|c|}
\hline $\mathbf{S} / \mathbf{N}$ & STATIONS & $\begin{array}{l}\text { CORDINATES } \\
\text { Latitude }\end{array}$ & Longitude & Site Description \\
\hline 1 & Station 1 & $\mathrm{~N}^{0} 21^{\prime} 35.3484^{\prime \prime}$ & $\mathrm{E}^{0} 1^{\prime} 46.9128^{\prime \prime}$ & Apparanbie Creek \\
\hline 2 & Station 2 & $\mathrm{~N}^{0} 21^{\prime} 54.4212^{\prime \prime}$ & E6 ${ }^{0} 2^{\prime} 7.5804^{\prime \prime}$ & Upstream \\
\hline 3 & Station 3 & N4021'44.5644' & $\mathrm{E}^{0} 2^{\prime} 20.2272^{\prime \prime}$ & Midstream \\
\hline 4 & Station 4 & $\mathrm{~N}^{0} 20^{\prime} 59.6472^{\prime \prime}$ & E6 ${ }^{0}{ }^{\prime} 48.3036 "$ & Midstream \\
\hline 5 & Station 5 & $\mathrm{~N}^{0} 20^{\prime} 40.8552^{\prime \prime}$ & $\mathrm{E}^{0} 2^{\prime} 56.4396^{\prime \prime}$ & Downstream \\
\hline 6 & Station 6 & $\mathrm{~N} 4^{0} 19^{\prime} 46.8048^{\prime \prime}$ & E6 $3^{\prime} 49.3596^{\prime \prime}$ & mud flat \\
\hline
\end{tabular}

\subsection{Sampling Procedure}

Fish samples were collected monthly for one year from six sampling sites in the River Nun estuary with the help of local skilled fishers. Cast nets, scoop nets, gill nets, beach seine nets, pole seine nets, and hooks and lines were used for capturing fish. Different fish species were collected (purchased) from fishers at the different fish landings. Photographs of the different species were then taken with help of a digital camera. Fishes were brought to laboratory and preserved in $10 \%$ formalin solution in separate specimen jars according to the size of the species. Small fishes were directly placed in the $10 \%$ formalin solution, while large fishes were given an incision in their abdomen and preserved. All fish species were identified to genus and species level using taxonomic keys and standard literature ${ }^{[4.5]}$

\subsection{RESULTS AND DISCUSSION}

Table 2: Checklist of fishes in the Nun River Estuary

\begin{tabular}{|c|c|c|c|c|}
\hline \multicolumn{2}{|l|}{ TAXON } & \multirow{2}{*}{ COMMON NAME } & \multirow[t]{2}{*}{ LOCAL NAME } & \multirow[t]{2}{*}{ STATUS } \\
\hline $\begin{array}{l}\text { Phylum: Chordata } \\
\text { Class Actinopterygii } \\
\text { Families }\end{array}$ & Species & & & \\
\hline Hepsedae & Hepsetus odoe & African River Pike & Ahagu & + \\
\hline Dasyatidae & Potamotrygon garociensis & Sting ray & Hika & + \\
\hline Soleidae & Synoptura cadenati & Sole fish & Alapu & ++ \\
\hline Elopidae & Elops senegalensis & Senegal ladyfish & & + \\
\hline \multirow[t]{2}{*}{ Clupeidae } & Ethmalosa fimbriata & Bonga shad & Afaru & ++++ \\
\hline & Ethmalosa Spp. & Bonga shad & Kigbo & ++ \\
\hline \multirow[t]{4}{*}{ Claroteidae } & Chrysichthys nigrodigitatus & Silver Cat fish & Henge & ++ \\
\hline & Chrysichthys furcutus & Silver cat fish & Henge & ++ \\
\hline & Chrysichthys araratuslengifills & Small silver cat fish & otio & ++ \\
\hline & Auhenoglanis occidentalis & Cat fish & Olokohenge & + \\
\hline \multirow[t]{4}{*}{ Carangidae } & Selene glosalis & & & + \\
\hline & Microphilis bracghyarus aculeatus & & & + \\
\hline & Caranx hippos & & & + \\
\hline & Eucinostomus melanopterus & & Ituburu & ++ \\
\hline Monodactylidae & Monodactilus sebae & African moony & Ofo & + \\
\hline \multirow[t]{7}{*}{ Cichlidae } & Lates niloticus & Red belly tilapia & Tomi & + \\
\hline & Coptodon zilli/ Tilapia zilli & Tilapia & Atabala & ++ \\
\hline & Tilapia Guineensis & Guinea tilapia & Okoroba & ++ \\
\hline & Sarotheridon melanotheron & Blackchin tilapia & Atabala & ++ \\
\hline & Sarotheridon galileaus & Mongo tilapia & Atabala & ++ \\
\hline & Tilapia nilofica & & & + \\
\hline & Tilapia galilaea & & & + \\
\hline Lobotidae & Lobotes surinamensis & Tilapia & Elepein & ++ \\
\hline Serranidae & Epinephelus aeneus & White grouper & & + \\
\hline \multirow[t]{4}{*}{ Mugilidae } & Mugil curema & White mullet & Gbulu & ++++ \\
\hline & Mugil bananensis & Banana mullet & Ideke & ++++ \\
\hline & Liza falcipinnis & Sickle fin mullet & Twein & ++ \\
\hline & Liza grandisquamis & Sickle fin mullet & Akura & +++ \\
\hline \multirow[t]{3}{*}{ Polynemidae } & Galeoides decadactyylus & Lesser African threadfin & Indabutu & ++ \\
\hline & Polydactylus quadrifilis & Giant African thread fin & Inda & ++ \\
\hline & Pentanemus quinquarius & Royal threadfin & Indabutu & ++ \\
\hline Oxudercidae & Periophthalmus barbarus/ papilio & Atlantic mudskipper & Itilai & +++ \\
\hline
\end{tabular}


Gijo, A. H. et.al. Ichthyofaunal diversity of The River Nun Estuary, Niger Delta, Nigeria.

\begin{tabular}{|c|c|c|c|c|}
\hline \multicolumn{5}{|c|}{ Table 2 Continued... } \\
\hline \multirow[t]{5}{*}{ Gobiidae } & Gobiodes segitta & & & + \\
\hline & Bathygobius soporator & Frillfin goby & & + \\
\hline & Porogabius schlegalli & Gobies & & + \\
\hline & Awaousla teristriga & & & + \\
\hline & Eleotris senegalensis & & & + \\
\hline Soleidae & Degetichthys lakdoensis & Sole fish & Alapu & ++ \\
\hline Cynoglossidae & Cynoglossus spp & Sole fish & Alapu & ++ \\
\hline \multirow[t]{2}{*}{ Tetraodontidae } & Tetra odonlineafus & Puffer fish & Ibubu & + \\
\hline & Tetra odonpustulatus & Puffer fish & Ibubu & + \\
\hline Characidae & Alestis nurse & & Ikolokolo & + \\
\hline Carangidae & Selene glorsalis & & & + \\
\hline \multirow[t]{3}{*}{ Sphyraenidae } & Sphyraena afra & Barracuda & Mendiogboro & ++ \\
\hline & Sphyraena barraccuda & Barracuda & Mendiogboro & ++ \\
\hline & Sphyraena Sphyraena & Barracuda & Mendiogboro & ++ \\
\hline \multirow[t]{2}{*}{ Carangidae } & Chloroscombrus chrysurus & & & + \\
\hline & Hemicaranx bicolor & & & + \\
\hline Haemulidae & Pomamadasys peroteti & & Ituburu & ++ \\
\hline \multirow[t]{2}{*}{ Sclaenidae } & Pseudotolithus (Foniticulus) elongatus & Croaker & Ona & +++ \\
\hline & Pseudotolithus typus & Croaker & Gbou & +++ \\
\hline Trichiuridae & Trichiurus lipterus & Cutlass fish & Mendiogidi & + \\
\hline
\end{tabular}

Table 3: Seasonal variation of fish in River Nun

\begin{tabular}{|c|c|c|c|}
\hline $\mathbf{S} / \mathbf{N}$ & Name of Fish & $\begin{array}{l}\text { Wet } \\
\text { season }\end{array}$ & $\begin{array}{l}\text { Dry } \\
\text { season }\end{array}$ \\
\hline 1 & Hepsetus odoe (African River Pike) & + & ++ \\
\hline 2 & Potamotrygon garociensis (Sting ray) & ++ & + \\
\hline 3 & Synoptura cadenati (Sole fish) & ++ & ++ \\
\hline 4 & Ethmalosa fimbriata (Bonga shad), & ++ & + \\
\hline 5 & $\begin{array}{l}\text { Chrysichthys nigrodigitatus, Chrysichthys furcutus, Chrysichthys araratuslengifills, and Auhenoglanis } \\
\text { occidentalis }\end{array}$ & ++ & + \\
\hline 6 & Eucinostomus melanopterus & + & ++ \\
\hline 7 & Monodactilus sebae (African moony) & + & ++ \\
\hline 8 & $\begin{array}{l}\text { Coptodon zilli/ Tilapia zilli (Tilapia), Tilapia Guineensis (Guinea tilapia), Sarotheridon melanotheron } \\
\text { (Blackchin tilapia), Sarotheridon galileaus (Mongo tilapia), Tilapia nilofica, and Tilapia galilaea }\end{array}$ & ++ & + \\
\hline 9 & $\begin{array}{l}\text { Mugil curema (White mullet), Mugil bananensis (Banana mullet), Liza falcipinnis (Sickle fin mullet), and } \\
\text { Liza grandisquamis (Sickle fin mullet) }\end{array}$ & + & ++ \\
\hline 10 & Galeoides decadactylus(Lesser African threadfin) and Pentanemus quinquarius (Royal threadfin)- & + & ++ \\
\hline 11 & Giant African thread fin (Polydactylus quadrifilis) & + & + \\
\hline 12 & Atlantic mudskipper(Periophthalmus barbarus/ papilio) & + & + \\
\hline 13 & $\begin{array}{l}\text { The Guinea swamp eel (Ophisternon afrum), Tetra odonlineafus (Puffer fish) and Tetra odonpustulatus } \\
\text { (Puffer fish) }\end{array}$ & ++ & + \\
\hline 14 & Degetichthys lakdoensis (Sole fish) and Cynoglossus spp. (Sole fish) & ++ & + \\
\hline 15 & Alestis nurse (local name: Ikolokolo) & -- & ++ \\
\hline 16 & Ilish Africana(Bonga) & -- & ++ \\
\hline 17 & Barracudas (Sphyraena afra, Sphyraena barracuda, and Sphyraena Sphyraena & ++ & + \\
\hline \multirow[t]{2}{*}{18} & Pomamadasys peroteti & + & ++ \\
\hline & Croakers Pseudotolithus (Foniticulus) elongates and Pseudotolithus typus & ++ & + \\
\hline
\end{tabular}

-- Absent +Less Abundant ++ More Abundant

The results of the ichthyofauna survey of the River Nunestuary are presented in Tables 2 and 3. Sixty (60) species of 48 different genera and 27 families were recorded during the study. The families Cichlidae and Gobiidae had the highest number of species (7 species each) followed by the families Claroteidae, Carangidae, Mugilidae, and Characidae (which had 4 species each), Polynemidae (with 3 species), and Clupeidae Tetraodontidae, Carangidae, Sclaenidae (with 2 species each). The families Hepsedae, Dasyatidae, Soleidae, Elopidae, Monodactylidae, Lobotidae, Periophthalmidae, Ophichthidae, Soleidae, Cynoglossidae, Tetraodontidae, Serranidae, Clupeidae, Carangidae, and Haemulidae had just one species. All the species of fish that were collected from the River Nun estuary 
belong to the Class Actinopterygii of the Phylum Chordata. Also, they all belong to the Super Class Gnathostomata (jawed vertebrates) - Table 2 and Plates 1 to 16.
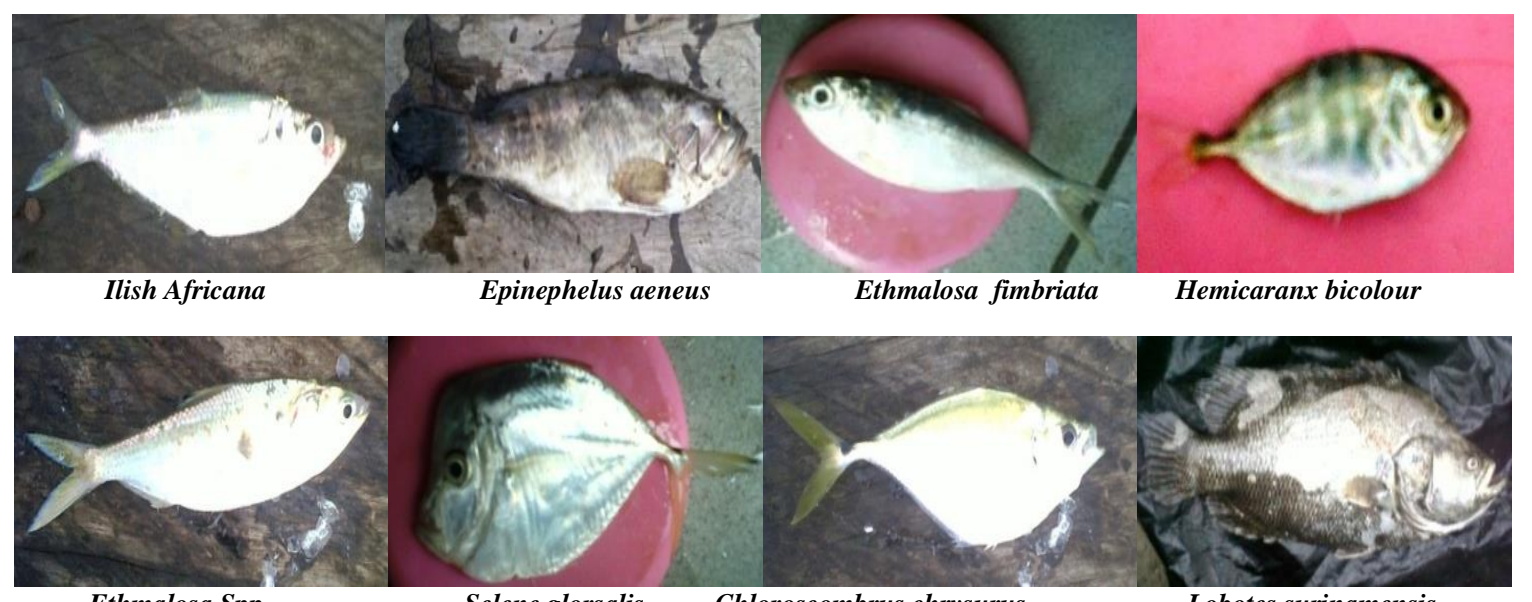

Ethmalosa Spp

Selene glorsalis

Chloroscombrus chrysurus

Lobotes surinamensis

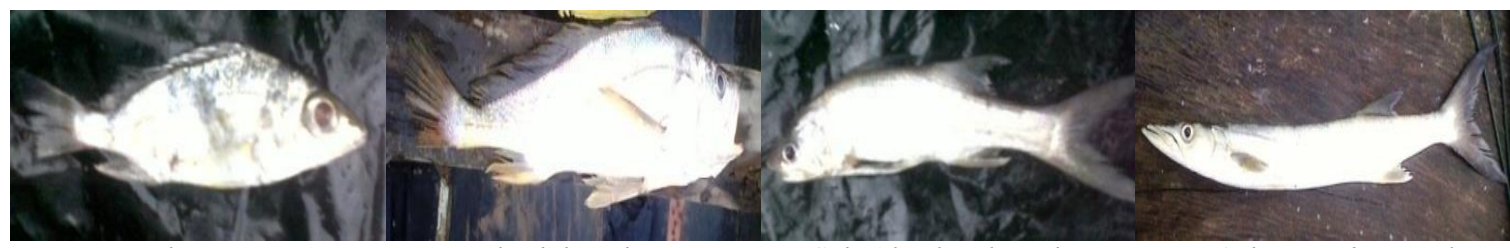

Pomamadasys peroteti

Pseudotolithus elongates

Galeoides decadactyylus

Sphyraena barracuda

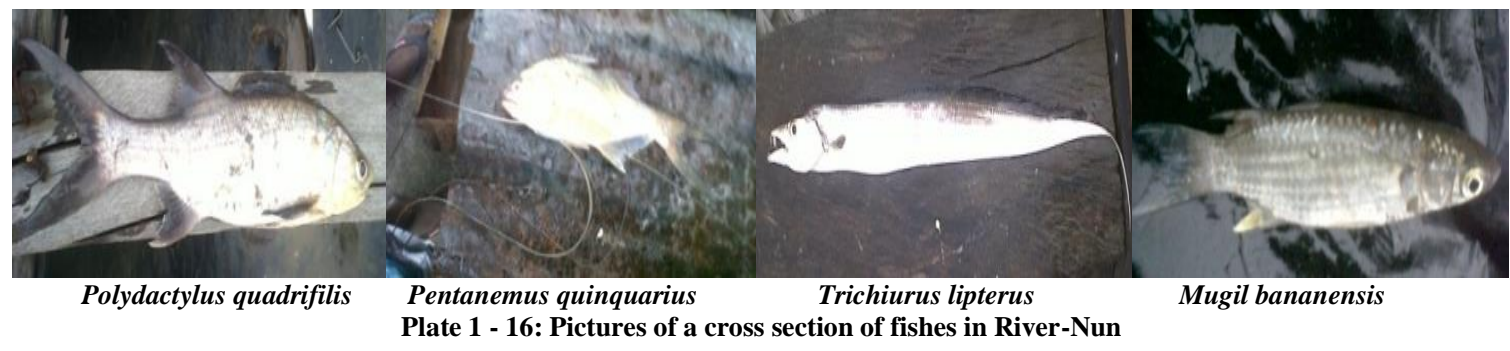

The fish Ethmalosa fimbriata (Bonga shad) of the of the Order Clupeiformes and family Clupeidae was the most abundant species of the River Nun estuary, followed by Pseudotolithus (Foniticulus) elongates (Croaker) of the family Sclaenidae, Periophthalmus barbarous/ papilio (Atlantic mudskipper) of the family Periophthalmidae, Mugil curema (White mullet), Mugil bananensis (Banana mullet), and Liza grandisquamis (Sickle fin mullet) of the family Mugilidae (Table 2). Ethmalosa fimbriata (Bonga shad) is mostly caught with the beach seine nets, gill nets, and cast nets. Periophthalmus barbarous/ papilio (Atlantic mudskipper), which is an amphibious fish, can be caught with the cast net but visual count and observation was mostly used during this study. They are usually abundant on muddy sediments on the shores and usually very active at low tides (ebb tides). Mugil curema (White mullet), Mugil bananensis (Banana mullet), and Liza grandisquamis (Sickle fin mullet) were caught with the aid of beach seine nets from the mud flats, when the mud flats are covered by water.

It was observed that the ichthyofauna of theRiver Nun estuary exhibited temporal (seasonal) and spatial variation. For instance, Hepsetus odoe (African River Pike), of the family Hepsedae was more abundant during the dry season in the brackish water areas of Minibie, Ereweibi, Buoama, and Appanbie creeks. Potamotrygon garociensis (Sting ray), of the family Dasyatidae was more abundant during the wet season. Synoptura cadenati (Sole fish) of the family Soleidae was caught during both dry and wet seasons. 
Ethmalosa fimbriata (Bonga shad), of the family Clupeidae was seen abundantly during the wet season in the months of June and July. Ethmalosa Spp. (Bonga shad) was most abundant during the dry season (November and December). The silver cat fishes, Chrysichthys nigrodigitatus, Chrysichthys furcutus, Chrysichthys araratuslengifills, and Auhenoglanis occidentalis of the family Claroteidae were found during both wet and dry seasons, but were more abundant during the wet season. Eucinostomus melanopterus, of the family Carangidae was available in the dry season (January to March). Monodactilus sebae (African moony) of the family Monodactylidae and Lates niloticus(Red belly tilapia) of the family Cichlidae were found during the dry season. Coptodon zilli/ Tilapia zilli (Tilapia), Tilapia Guineensis (Guinea tilapia), Sarotheridon melanotheron (Blackchin tilapia), Sarotheridon galileaus (Mongo tilapia), Tilapia nilofica, and Tilapia galilaea all of the family Cichlidae were seen during the wet season when the water in the estuary is diluted by fresh water from rain fall and from the fresh water environments. Mugil curema (White mullet), Mugil bananensis (Banana mullet), Liza falcipinnis (Sickle fin mullet), and Liza grandisquamis(Sickle fin mullet) of the family Mugilidae and were abundant during the dry season and part of the wet season (January to June) and were caught from around mudflats that were covered with water. They were mainly caught with beach seine nets. Galeoides decadactylus (Lesser African threadfin) and Pentanemus quinquarius (Royal threadfin)- that are both locally called Indabutu of the order Perciformes and family polynemidae were also abundant during the dry season and part of the wet season (January to June) and were caught with beach seine nets, gill nets, hook and lines, and with nets that were locally used to catch crayfish. They were caught from around mudflats that were covered with water and also from the deep parts of the estuary. However, the Giant African thread fin (Polydactylus quadrifilis) of the same order Perciformes and family polynemidae was abundant from June to December (wet and dry seasons) and was mainly caught with gill nets that have large mesh sizes.

Furthermore, Atlantic mudskipper (Periophthalmus barbarus/ papilio) of the order Gobiiformes and family Oxudercidae was abundant throughout the year (January to December). It occurs on tidal mud flats, some sandy shores, on mangroves, concretes, and other substrata along the shores of the estuary were it readily crosses mud, sand and concrete surfaces out of the water, using its pectoral fins and tail to move. The Guinea swamp eel (Ophisternon afrum) of the order Synbranchiformes and family Synbranchidae as well as Tetra odonlineafus (Puffer fish) and Tetra odonpustulatus (Puffer fish) were caught during the wet season (June to August) and the inhabitants of the area don't eat them. Degetichthys lakdoensis (Sole fish) of the family Soleidae and Cynoglossus spp. (Sole fish) of the family Cynoglossidae were available during wet season and the dry season but were more abundant during the wet season during the months of June and July. They were caught mainly with the gill nets that have anchors that were set around the mudflats and left-over night.

Also, Alestis nurse (local name: Ikolokolo) of the family Characidae occurs only during the dry season (November to December) which are usually caught by luring them with palm oil and then scooped with the scooping nets. Furthermore, Ilish Africana (Bonga) of the family Clupeidae was available only during the dry season. However, the Barracudas (Sphyraena afra, Sphyraena, barracuda, and Sphyraena Sphyraena) of the family Sphyraenidae were available all year round but were more abundant during the wet season (June to August). Pomamadasys peroteti of the family Haemulidae was available during the dry season, from January to March. Furthermore, the Croakers Pseudotolithus (Foniticulus) elongates and Pseudotolithus typus of the family Sclaenidae were caught 
throughout the year (January to December). However, they were more abundant during the wet season. Pseudotolithus (Foniticulus) elongates was more abundant from June to July, while Pseudotolithus typus was more abundant from September to November.

\section{CONCLUSION}

In conclusion, this study has provided data about the ichthyofaunal diversity of the River Nun estuary. The Nun River estuary is endowed with high ichthyofaunal diversity. Fishing is carried out throughout the year and with various fish gears. However, the fish population in this estuary are declining as they are been depleted faster than they are able to restore their number. This study identified and recommends conservation and friendly environmental approaches to fishing and fish farming should be enhanced to provide for the growing demand among the populace. This will encourage fisheries resources conservation as well as farmed fish production and enhance more jobs for the local people.

Acknowledgement: None

Conflict of Interest: None

\section{Source of Funding: None}

\section{REFERENCES}

1. Allison, M. E. The Ecology and Fishery of Parailia pellucida (Boulenger 1901) (Shilbeidae) in Lower Nun River of the Niger Delta. Unpublished PhD Dissertation, University of Port-Harcourt. 2006: 267 pp.

2. Abowei, J. F. N. and Hart, A.I. Some morphometric parameters of ten finfish species from the Lower Nun River, Niger Delta, Nigeria Research Journals of Biological Sciences, 2009:4 (3): 282-288.

3. Knight W. D., Alagoa N. C., Kemedi, D. V. (2000). Akassa: A New Approach to the Problems of the Niger Delta.

4. F.A.O. Species Identification Sheets for Fishery Purposes. Fischer, W., Bianchi, G. and Scott, W.B. (ed). Easter Central Atlantic; fishing areas. 1981: 34, 47.

5. Idodo-Umeh, G. Fresh water fishes in Nigeria, (Taxonomy, Ecological notes, Diets and Utilization). Idodo-Umeh Publishers, Benin City. Nigeria. 2003:pp 123-124.

How to cite this article: Gijo, A. H., Alagoa, K. J. Ichthyofaunal diversity of The River Nun Estuary, Niger Delta, Nigeria. International Journal of Research and Review. 2022; 9(2): 274-280. DOI: https://doi.org/10.52403/ijrr. 20220237 